\title{
Skyld og skam
}

\section{Skyld og skam. Ikke TV-serien, men den sosiale reaksjonen. Skammen er voldsom, den er giftig, og det er en følelse vi bør snakke mer om.}

Skam oppstår når egne handlinger er et brudd med egne eller samfunnets idealer eller forventninger. Skyldfølelse er å bryte med seg selv. Men skammen er noe mer. Skammen er å bli avdekket, å bli avslørt, å bli sett for hva du «virkelig er».

Denne avdekkingen er til tider påført rent bokstavelig. Gåturen hjem etter en natt der du helt tydelig ikke sov i egen seng. Hevnporno, der forsmådde ekser deler nakenbilder for å hetse eksen, er også i denne gamle tradisjonen med på å påføre offentlig skam på kvinner ved å avdekke at de har en seksualitet. Påføring av skyld og skam er et kraftig våpen.

Alle er en front og har en eller flere usette realiteter. Vi spiller roller mot hverandre, i kostymer og med rekvisitter som støtter oppunder rollen vi spiller ut på scenen der andre ser. Det er ikke en ibsensk livsløgn, men en avtale mellom aktørene om en passende setting som skal spilles ut, der vi konsekvent opprettholder vår rolle versus resten av skuespillerne i hverdagssettingen.

Fronten er ikke bare tomhet, som de overlykkelige postene på Facebook blir anklaget for å være. Fronten er din identitet. Du er en mor, du er en sånn som trener, du er en glad og jovial arbeidskar.

Skam er når denne hverdagslige, kon- sekvente rollen brytes av å bli sett av den andre, at den andre ser bak kostymet - et brudd ikke bare med samfunnets forventninger, men med din selvoppfatning.

Og hvorfor er denne følelsen viktig for folk som jobber med helse og sosiale utfordringer? Fordi skam står sentralt i noen av de største helseutfordringene vi har. Sekkeposten «milde til moderate psykiske lidelser» kan for eksempel føre med seg enorme brudd med personen du fronter til vanlig. Den arbeidsomme klarer ikke å stå opp om morgenen og blir sykemeldt. Den joviale familiefaren blir irritabel og vanskelig å være i hus med. Den tidligere så Instagram-perfekte damen med strøkent hjem får svikt i boevnen og slutter å dusje. Den fotballspillende ungdommen får angst og nekter å dra på skolen eller trening.

Hvordan skal du som skammer deg egentlig klare å fortelle omverdenen hva som er galt? Når det å påføre skam er sterkt nok til at det kan brukes som et effektivt våpen. Hvordan skal du orke å påføre deg selv denne følelsen? Svaret er selvfølgelig å lyve, enten direkte eller ved unnvikelse. A prokrastinere med det nødvendige, å utsette legebes $\varnothing$ ket, eller å plassere bort problemet, enten ved en sterkere front eller ved å gjemme seg vekk.

Jeg har følt på det selv, hos legen eller psykologen. Selv om jeg er drillet i at man ikke skal underdrive, det er grunnleggende nødvendig aldri å underdrive om du skal få hjelp. Jeg drar det frem i foredrag og formaner folk til å vite at legen har sett det meste av det flaue før. Om det gjelder en klump på ballene, depresjon eller rusmisbruk, er det uansett bare en hverdag for helsepersonell.Men sitter den kunnskapen sterkere enn skammen? Absolutt ikke.

I praksis betyr det hele å bestille legetime for sjelden - om det er noe som ikke passer seg for «sånne som deg». Og å presentere seg mer finslig. Jeg er hellig overbevist om at kvinner blir for sent diagnostisert med både det ene og det andre fordi vi sminker vekk gusten hud og bleke våtlinjer, og tar den første dusjen på to uker før legetimen.

Så blir vi spurt om hvordan vi har det. Jo takk, bare bra, sover litt dårlig.

Skammen er til og med regnet med i diagnoseverktøyene for et av de mest skamfulle områdene i folkehelsen: alkohol. Her er et spørsmål en del av leserne antagelig kjenner igjen. Etter noen spørsmål om frekvens og mengde kommer det, der du sitter på et kontor foran en kjernesunn autoritet på Riktig Levnad: «7. Hvor ofte i løpet av det siste året har du hatt skyldfølelse pga. drikking?»

Paradokset burde være åpenbart: Det var kanskje ikke meningen å lyve eller underdrive, men hvilken pasient ønsker å blottlegge seg sånn? Så svarer man da. Nei. Ikke noe skam for meg.

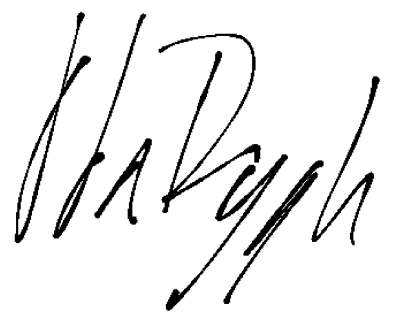

